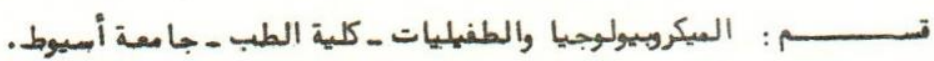

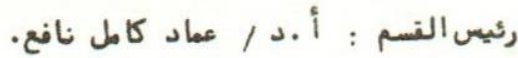

د راسة بالميكروسكوب العاد ي والا ليكترونى للتركيب الد قيق لنوع من الساركوستستس العمزول

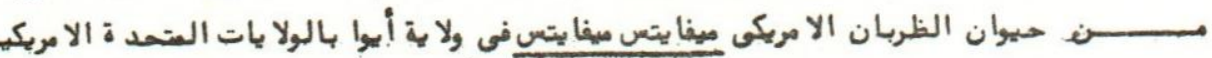

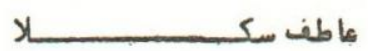

د رسلا ول مرة التركيب الد قيق لنع من الساركوستستس المعزول من حيوان الظربان الا مريكى بولاية أيوا الامريكية.

وقد شعلت الد راسة التركيب الد قيق لكل من جد ار الهويصلات والزوتيات والميترويستلاتلهيذا

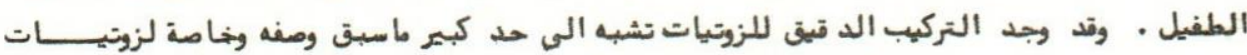

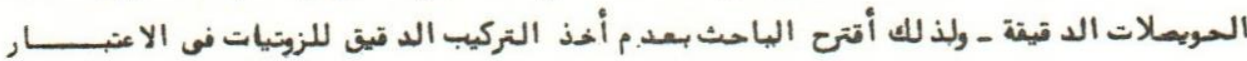

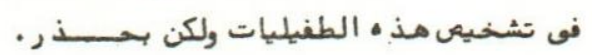

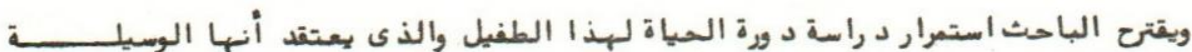

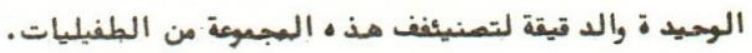


Dept. of Parasitology \& Microbiology,

Faculty of Medicien, Assiut University.

Head of Dept., Prof. Dr. E.K. Nafie.

\title{
LIGHT AND ELECTRON MICROSCOPIC STUDIES ON SARCOCYSTIS SPECIES FROM THE STRIPPED SKUNK, MEPHITIS MEPHITIS IN IOWA, U.S.A.
}

(With 8 Figures)

By

A.A. SAKLA

(Received at 25/4/1982)

\section{SUMMARY}

\begin{abstract}
Sarcocystis sp. have been found naturally in the skeletal muscle of a stripped skunk, Mephitis mephitis captured from Iowa state, U.S.A. Light and electron microscopic appearance of this parasite has been studied. U1tra-structure of the cyst wall as well as the zoites were described, compared and discussed. The present study deals, for the first time, with the Pine structure of a Sareocystis species from the stripped skunk, Mephitis mephitis.
\end{abstract}

\section{INTRODUCTION}

More than seventy species of Sarcocystis have been reported and named. They are differentiated on the basis of the host, the structure of the cyst wall as well as the size of the zoites, LEVINE (1977).

So far, the ultra-structure of some species of Sarcocystis have been studied. Thus, LUDVIK (1958 \& 1960) have described the fine structure of S.tenella and S.miescheriana; SENAUD and PUYTORAC (1961) and SENAUD (1965) on S.tenella; MANDOUR et al. (1965) on a Sarcocysytis sp. from harsh-furred rat, Lophuromys plavopunctatus; SIMPSON (1966) and SIMPSON and FORRESTER (1973) on S.tenella and Sarcocystis sp.; MANDOUR (1971 \& 1974) on S. kortel from rhesus monkey and $\underline{S}$.blanchard1 from Egyptian buffalo; MEHLHORN and SCHOLTYSECK (1973) on $\underline{\mathrm{S}}$. tenella of sheep and MEHL.HORN et al. (1975 a,b \& c). On S. Pusiformis.

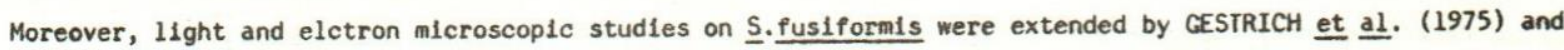

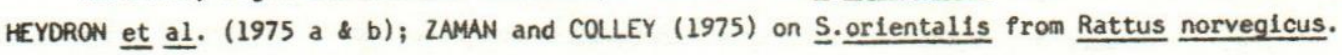

Recently, MEHLOHORN et al. (1976) studied the ultra-structure of thirteen Sarcocystis spp. cyst wall; RZEPCZYK and SCHOLTYSECK (1976) on a Sarcocystis sp. Prom Rattus fuscipes; KAN and DISSANAIKE (1977) on a Sarcocystis sp. from Rattus rattus diard1i, KAN (1979) on Sarcocystis spp. from Malaysian rodents; ABDEL GHAFFAR et al. (1979) on a Sarcocystis sp. from Camelus dromedarius; BEAVER and MALECKAR (1981) on S.singaporensis, $\underline{\text { s.vil- }}$ livillosi and $\underline{\mathrm{S}}$.zamani from Rattus norvegicus.

The present work deals with the fine structure of Sarcocystis sp. from stripped skunk, Mephitis mephitis.

\section{MATERIAL and METHODS}

Skeletal muscles: were collected from freshly sacrified stripped skunk infected naturally with Sarcocystis. Portions of skeletal muscles were squashed between two slides and examined microscopically. For ligyt microscopic studies, the infected specimens were pixed in Bouin's fixative.Paraffin sections were stained with Haematoxylin and eosin. Impression smears form the cut surface of the infected mucles were fixed in absolute alcohol and stained with Ciemsa's stain. For electron microscopic studies, the infected'materials were fixed in the glutaraldehyde in Millonig's buffer, PH 7.4, for 24 hours. Specimens were placed in 280 s04 in Millonig's phosphate buffer. Sections were stained in $2 \%$ aqueous uranyl acetate and lead citrate and examined with a Philips 300 electron microscope. Original copies of the photo-micrographs were obtained for description and comments.

\section{RESULLTS}

Sarcocystis sp. cysts were found in the striated muscles throughout the body, including the tongue, oesophagus, and diaphragm, but not in the heart. 


\section{Light microscopic appearance:}

Haematoxylin and eosin stained sections of the microscopic cysts showed the Miescher's tube with thin cyst wall and thin trabeculae dividing the cyst.into numerous compartments enclosing small banana-shaped zoltes. The cysts were spindle shaped with rounded ends. The largest cysts were $500 \times 75 \mathrm{U}$, and cyst wall was $6 \mathrm{U}$ in thickness. The wall of the large cysts in sections of well-fixed tissue, stained with H\&E., appeared to have two distinct layers. The outer layer was $1.5 \mathrm{U}$ thick, weakly basophllic, and provided with fine, mostly erected, cilia-like processes or villi. The eosinophilic inner layer was approximately $0.8 \mathrm{U}$ thick and had the appearance of a thin line. In tangential sectlons of the wall, the villi were seen rounded. The Giemsa's stained smears contained a large number of minute benana-shaped zoites, approximately 7-8 $1.5-2 \mathrm{U}$. The nuclei were slightly elongated, and nearly as wide as the widest part, but not entirely fllling the posterior end. Its middle third contained deeply stained granules, while its anterior end was relatively light in colour.

\section{Electron microscopic appearance:}

The cyst wall: Large cilla-like processes or villi appeared projecting prom the outer layer of the cyst wall towards the hoist tissue (Fig. 1). The pellicle of the villus had a mamillated or serrated appearance when highly magnified (F1g. 2, 3 \& 4). In tangential sections, the number of the outer minute papillae on the outer surface of the villus was 20-30 (Fig. 5). Bundles of fine filamentous fibrils were seen running parallel to the long axis within the villus core (Fig. 1-5). These bundles, which form the central core of the villi, were found blended proximally in the stroma of the cyst wall, while they were separated from each other toward the free end of the villi (Fig. 1, 2 \& 3). A clear zone was also separating these bundles from the inner surface of the villus pellicle (Fig. 1-5). Around and between the vill1, they was a large number of host cell mitochondria, as well as, other elements of the host muscle cells (Fig. 4). The stroma of the inner layer of the cyst wall showed electron dense undifferentiated bodies which were darkly stained, of varying shapes and sizes (Fig. 5\& 6). Some of these bodies were subdivided into unequal portions by clefts. Thin septa of ground substance extended from the inner layer of the cyst wall into the cyst interior in which zoites were tightly packed assuming polygonal forms (Fig. 6). Metrocytes were much larger than the zoites and were seen only in contact with the ground substance of the inner layer of the cyst wall (Fig. 6).

The zoites: Mature zoites were surrounded with ultra-thin doubled-layer pellicle. Three divisible zones were the distinctive feature of the zoites stroma in longitudinal section (Fig. 7). The anterior pibrillar zone, was filled with fine convoluted microtubules, the sarconemes or micronemes. The anterior end of the fibrillar zone was occupied by the polar ring within which the conold was detected. In addition, the anterior zone showed club-shaped portions of the paired organelle, rhoptries (Fig. 7). A micropyle was observed fust under the pellicle and about the middle of the fibrillar zone (Fig. 8). The middle vesicular zone, contained a relatively large stained vesicles, as well as, large unstained vaculoes possibly pilled with lipid material. Within the middle zone, and near the nucleus lled the mitochondria. The posterior nuclear zone contained the nucleus which was nearly as wide as the cell. It was an ellipsoidal vesicle and contained an endosome and chromatin granules.

\section{DISCUSSION}

The finding of the electron microscopical examination of the skunk Sarcocystis observed in the present study were compared by the ultrastructure of the previously descrlbed species in the different hosts. However, and on the basis of the ultra-mprphological structure, it was found that the parasite under discussion closely resembles other species of Sarcocystis particularly the zoites of the microcyst producing parasites. Nevertheless, the detection of the fundamental structures characterestic to the Sarcocystis zoltes as the polar ring, conoid, micronemes, paired organelle, micropyle, mitochondrion, vacuoles, vesicles and nucleus were confirmed by a number of authors since the work of LUDVICK (1958). Accordingly, this study yielded evidence that some animal species may be intermediate hosts for one species. of Sarcocystis. Thus far, the present author kept the ident1fication of the present material at the generic level, because of the much controversy regarding the nomenclature of Sarcocystis parasites, a fact which was mentioned by LEVINE (1977). 


\section{SKUNK SARCOCYSTIS}

As far as the ultra-structure of the cyst wall of the skunk Sarcocystis, the present work revealed quite variations when compared with the previously described other parasites. However, it could be postulated that the fine structure of the Sarcocystis cyst wall could be used with care as a criteria to identify the different species of this parsite.

Further studies on the life history of the skunk Sarcocystis will permit complete and acurate identification to the species. It is worth-while mentioning that the present study deals, for the first time, with the ultra-structure of Sarcocystis parasite from the stripped skunk, Mephitis mephitis.

REFERENCES

Abdel-Ghaffar, F.; Entzeroth, R.; Chobotar, B. \& Scholtyseck, B. (1979): Ultra-structural studies of Sarcocystis sp. from camel (Camelus dromedarlus) in Egypt. Tropenmed. Parasitol., 30: 434-433.

Beaver, H.C. and Maleckar, J.R. (1981): Sarcocystis singaporensis Zaman and Colley (1975) 1976, Sarcocyst1s villivillosi sp. $n$; and Sarcocystls zamani sp. n., development, morphology and persistence in the laboratory rat, Rattus norvegicus. J. Harasitol. 67: 241-256.

Gestrich, R.; Mehlhorn, H. und Heydron, A.0. (1975): Licht-und elektronenmikroskopische Untersuchungen an Cysten von Sarcocystis fusiformis in der Muskulatur von Kalbern nach experimenteller Infektion mit Occysten und Sporocysten der grossen Form von Isospora bigemina der Katze. Zbl. Bakt., I. Abt. Orig. A, 232.

Heydorn, 0.; Mehlhorn, H. \& Gestrich, R. (1975 a): Licht- und elektronenmikoskopische Untersuchungen an Cysten von Sarcocystis fusiformis in der Muskulatur von Kalbern nach experimenteller Infektion mit Occysten und Sporocysten von Isospora hominis Railliet et Lucet, 1891. 2. Die Feinstruktur der Metrocysten und Merozoiten. Zbl. Bakt. Hyg., I. Abt. Orig. A, 232. 373-391.

(1975 b): Licht- und elektronenmikroskopische Untersuchungen an Cysten von Sarcocystis fusiformis in der Muskulatur von Rindern nach experimenteller Infektion mit Oocysten der grossen Form von Isospora bigemina des Hundes 2. Die Feinstruktur der Cystenstadien. Zbl. Bakt. Hyg., I. Abt. Orig. A, 233, 123-137.

Kan, S.P. (1979): Ultra-structure of the cyst wall of Sarcocystis spp. from some rodents in Malaysia. Int. J. Parasitol., 9: 475-480.

Kan, S.P. and Dissanaik, A.S. (1977): Ultra-structure of Sarcocystis sp. from the Malaysian house rat, Rattus rattus diardii. Z. Parasitenkd., 52: 219-227.

Levine, N.D. (1977): Nomenclature of Sarcocystis in the ox and sheep and of fecal coccidia of the dog and cat.J. Parasitol. 63: 36-51.

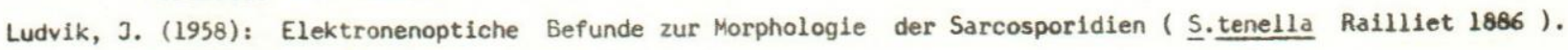
Zentbl. Bakt. Parasitkde., 172, 330.

(1960): The electron microscopy of Sarcocystis miescheriana Kuln, 1865. J. Protozool. 16, (2), 353.

Mandour, A.M. (1971): Fine structure of Sarcocystis kortei Castellani and Chalmers, 1909 from a rhesus monkey, Macaca mulatta. J. Egypt. Soc. Parasit., I, 29-37.

- (1974): Fine structure of Sarcocystis blanchardi Doflein, 1901 from the Egyptian buffalo. Assiut Vet. Med. J., 1: 101-105.

Mandour, A.M.; Bird, R.G. and Morris, M. (1965): Electron microscopic studies on Sarcocystis sp. in Lophuromys flavopunctatus from Kenya. Trans. roy. Soc. trop. Med. Hyg., 59, 360.

Mehlhorn, A.; Heydorn A.O. und Gestrich, R. (1975 a): Licht- und elektronenmikroshopische Untersuchungen an Cysten von Sarcocystis fusiformis in der Muskulatur von Kalbern nach expertmenteller Infektion mit Docysten und Sporocysten von Isospora hominis Raillet et Lucet, 1891. I. Zur Entstehung der Cyste und der Cystenwand. Zbl. Bakt. Hyg., I. Abt. Orig. A; 231-322.

Mehlhorn A.; Heydorn A.O. und Cestrich, R. (1975 b): Licht- und elektronenmikroskopische Untersuchungen an Cysten von Sarcocystis fusiformis in der Muskulator von Rindern nach experimenteller Infektion mit Docysten und Sporocysten der grossen Form von Isospora bigemina des Hundes. 1. Zur Entstehung der Cyste. Zbl. Bakt. Hyg., I. Abt. Orig. A, 232, 392-409. 


\author{
A.A. SAKLA
}

Mehlhorn, H.; Hartley, W.0. \& Heydorn, A.0. (1976): A comparative ultra-structural study of the cyst wall of 13 Sarcocystis species. Prot1stologica 12: 451-467.

Mehlhorn, A. \& Scholtyseck, E. (1973): Elktronemikroskop1sche Untersuchungen an Cystenstadian von Sarcocystis tenella aus der Oesophaguskulatur des Schafez. 2. Parasitenk., 41, 291-310.

Mehlhorn, H.; Senaud, J.; Heydorn, A.O. and Gestrich, R. (1975 c): Comparaison des ultrastructure des kystes de Sarcocystis fusiformis Railliet,1897 dans la musculature du boeuf, Apres infection naturelle et apres infection experimentale par des sporocystes d'Isospora hominis et par des sporocystes des grandes formes d'Isospora bigemina du chien et Du Chat. Protistologica, II 445-455.

Rzepezyk, C. and Scholtyseck, E. (1976): Light and electron microscope studies on the Sarcocystis of Rattus fuscipes. an Australlan rat. Z. Parasitenkd. 50: 137-150.

Senaud, J. (1965): Ultrastructure comparee des endodyoziftes de s.tenalla et de Toxoplasma gondi1. Progress in Protozoology, 219, 188.

Senaud, J. \& Puytorac, P. (1961): Sur l'ultrastructure de l'envelloppe kystique shez la sarcosporidie du mouton (S.

Simpson, C.F. (1966): Electron microscopy of Sarcocystis fusiformis. J. Parasit., 52, 607-613.

Simpson, C.F. \& Forrester,O.J. (1973): Electron m1croscopy of Sarcocystis sp. Cyst wall, micropore, choptries, and an unidentified body. Int. J. Parasitol. 3, 467-470.

Zaman, V. and Colley, F.C. (1975): Light and electron microscoplc observations of the life cycle of Sarcocystis orientalis sp. $n$. In the rat (Rattus norvegicus) and the Malaysian reticulated python (Python reticulatus). orientalis 2. Parasitenkd., 47, 169-185. 


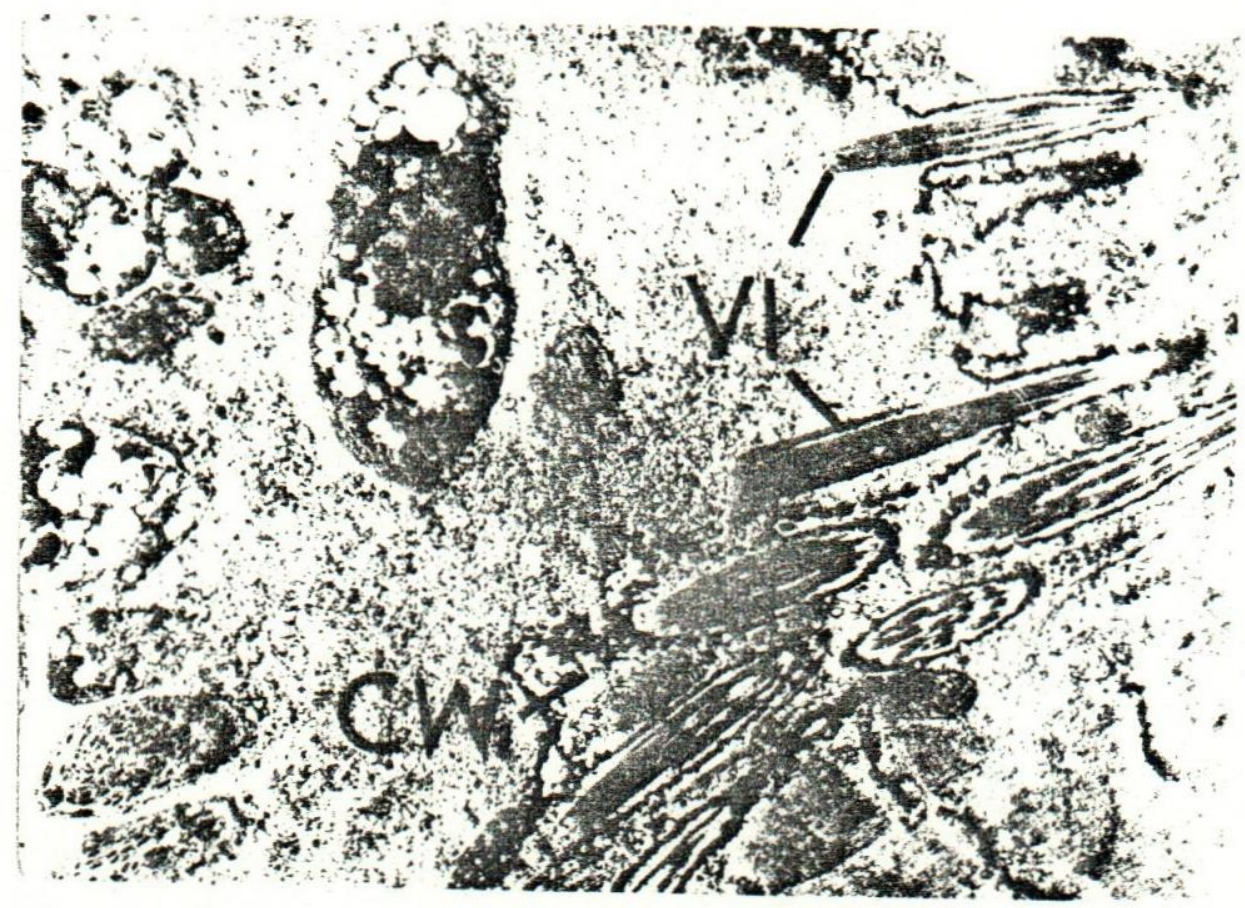

(Fig. 1): Electron micrograph of skunk Sarcocystis showing the cyst and wall villi. (X 5,000).

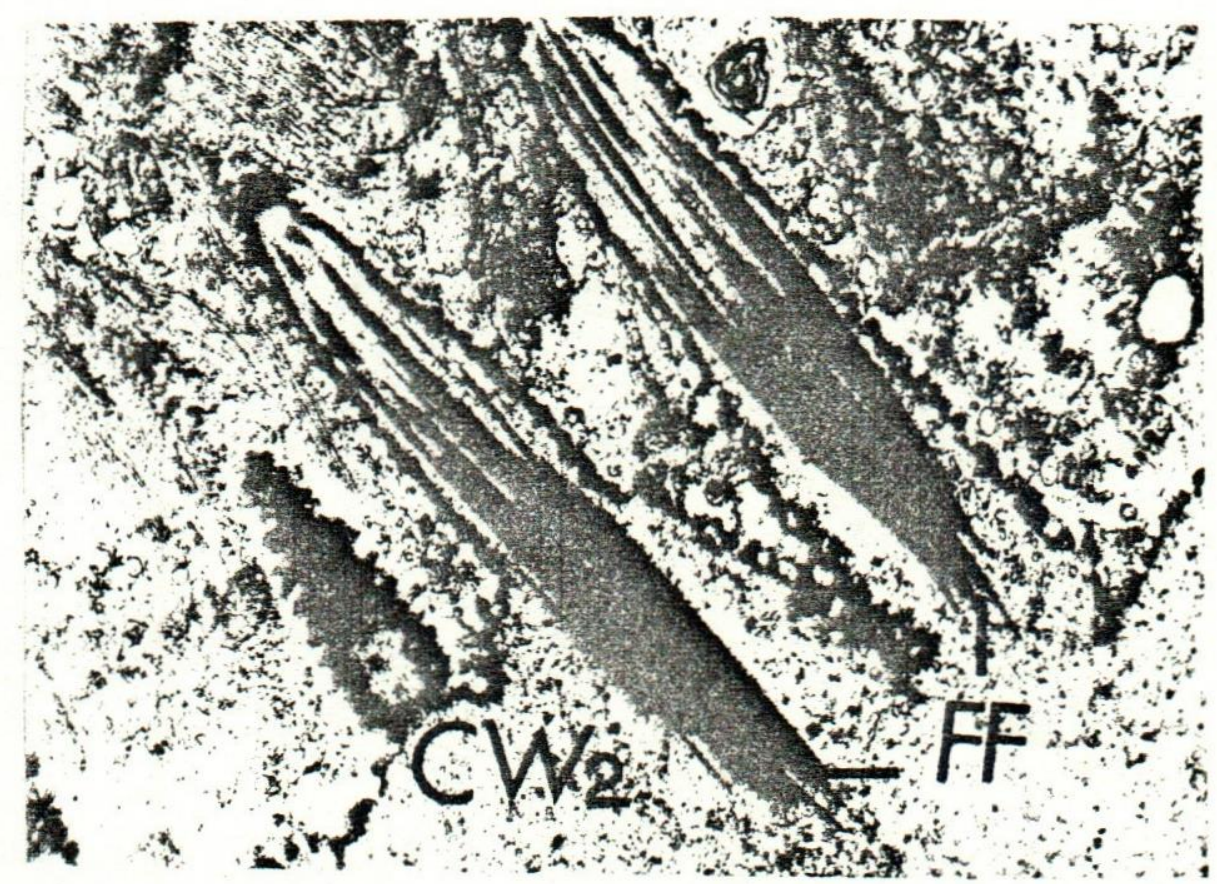

(Fig. 2): Electron micrograph of skunk Sarcocystis showing a portion of cyst wall and the villi with fine filamentous fibrils core (X 10,000). 


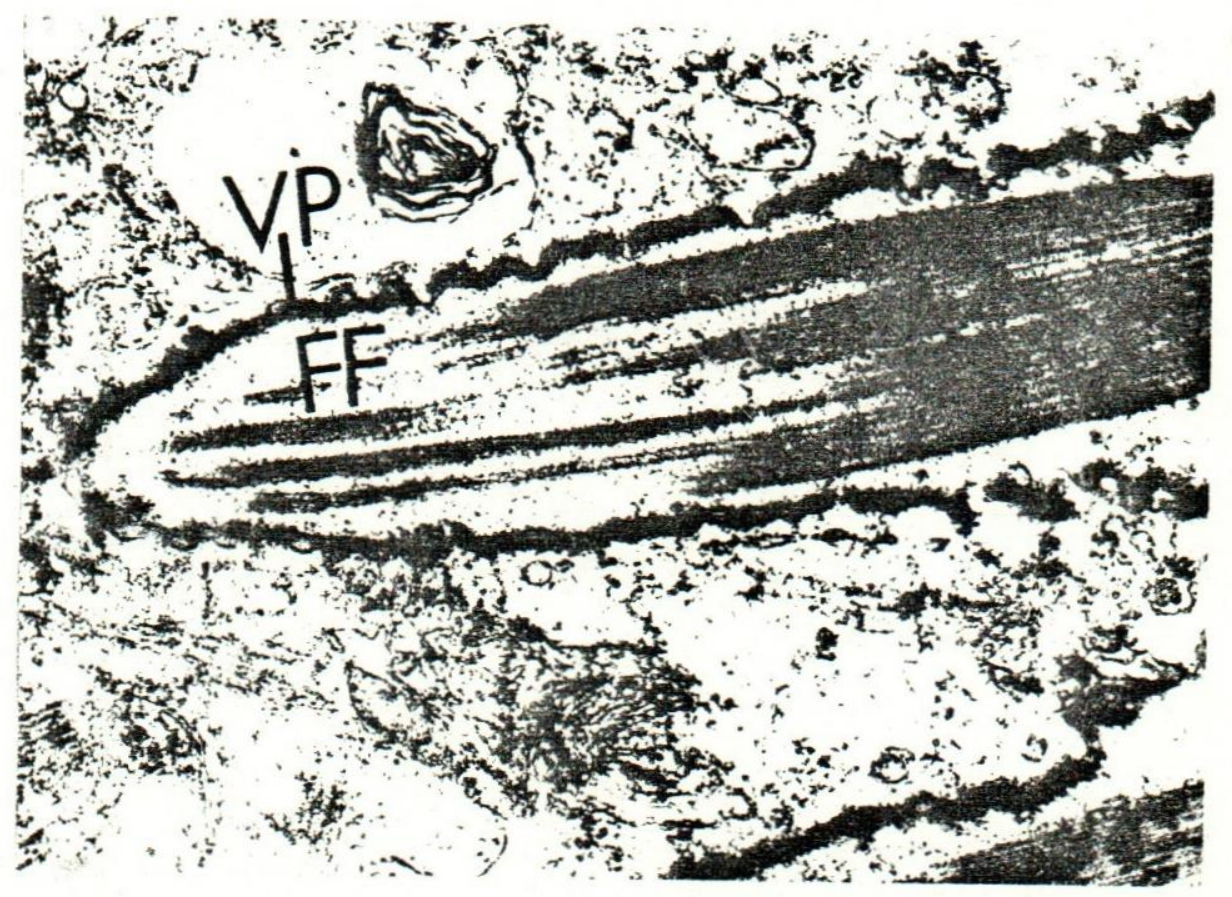

(Fig. 3): Electron micrograph of skunk Sarcocystis showing the papillated villus pellicle and the central villus core. (X 20,000).

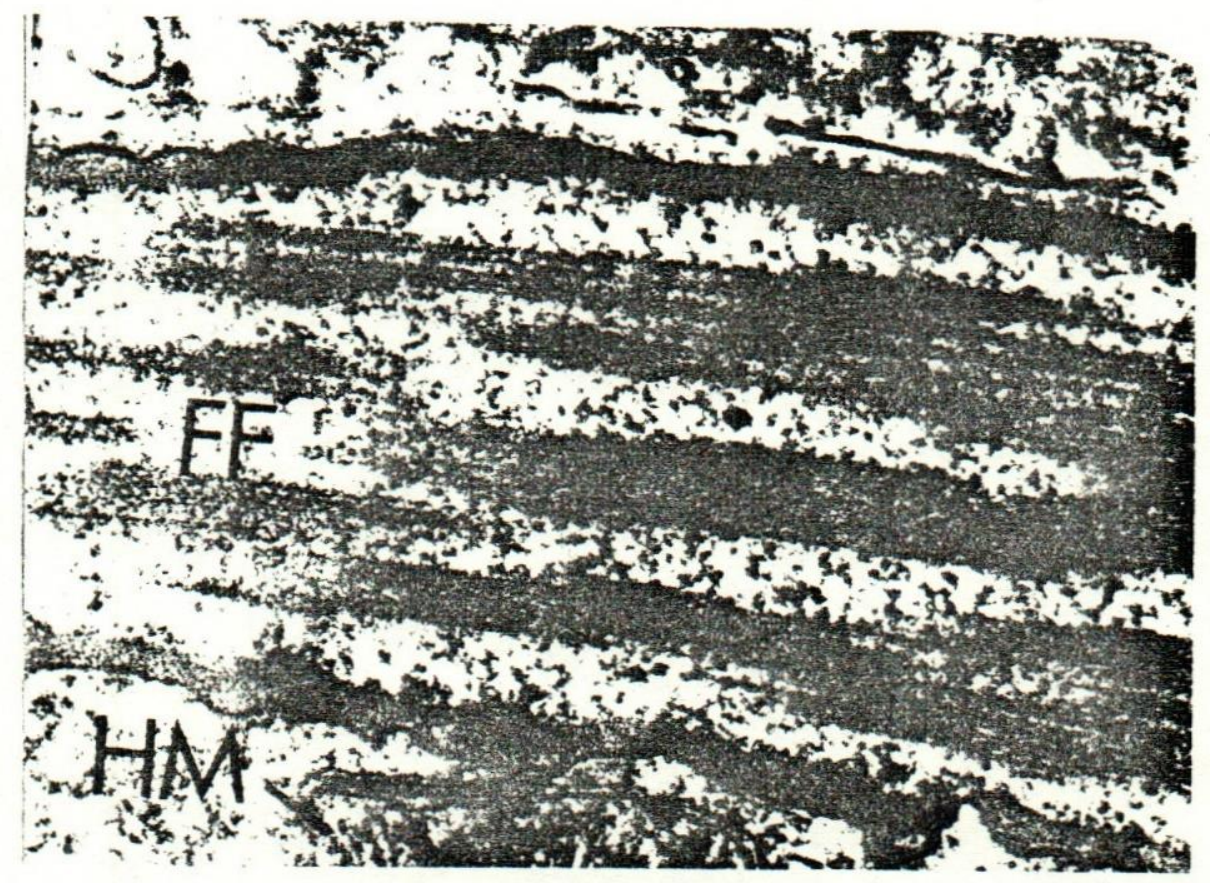

(Fig. 4): Electron micrograph of skunk Sarcocystis showing a highly magnified villus with separated fibrillar bundles. (X 50,000). 


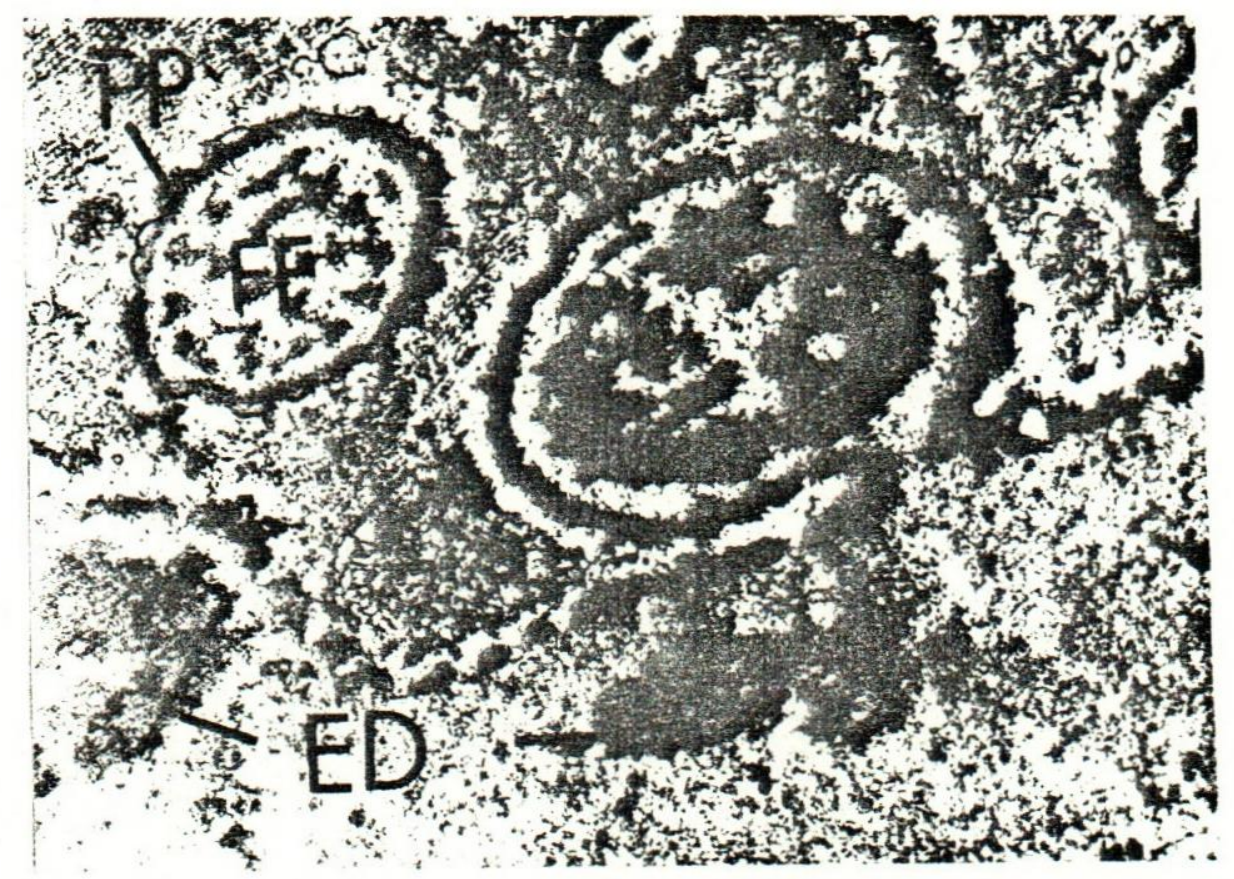

(Fig. 5): Electron micrograph of skunk Sarcocystis showing tangential sections in villus with papillae on its pellicle and fine fibrils in its core. ( $x$ 20,000).

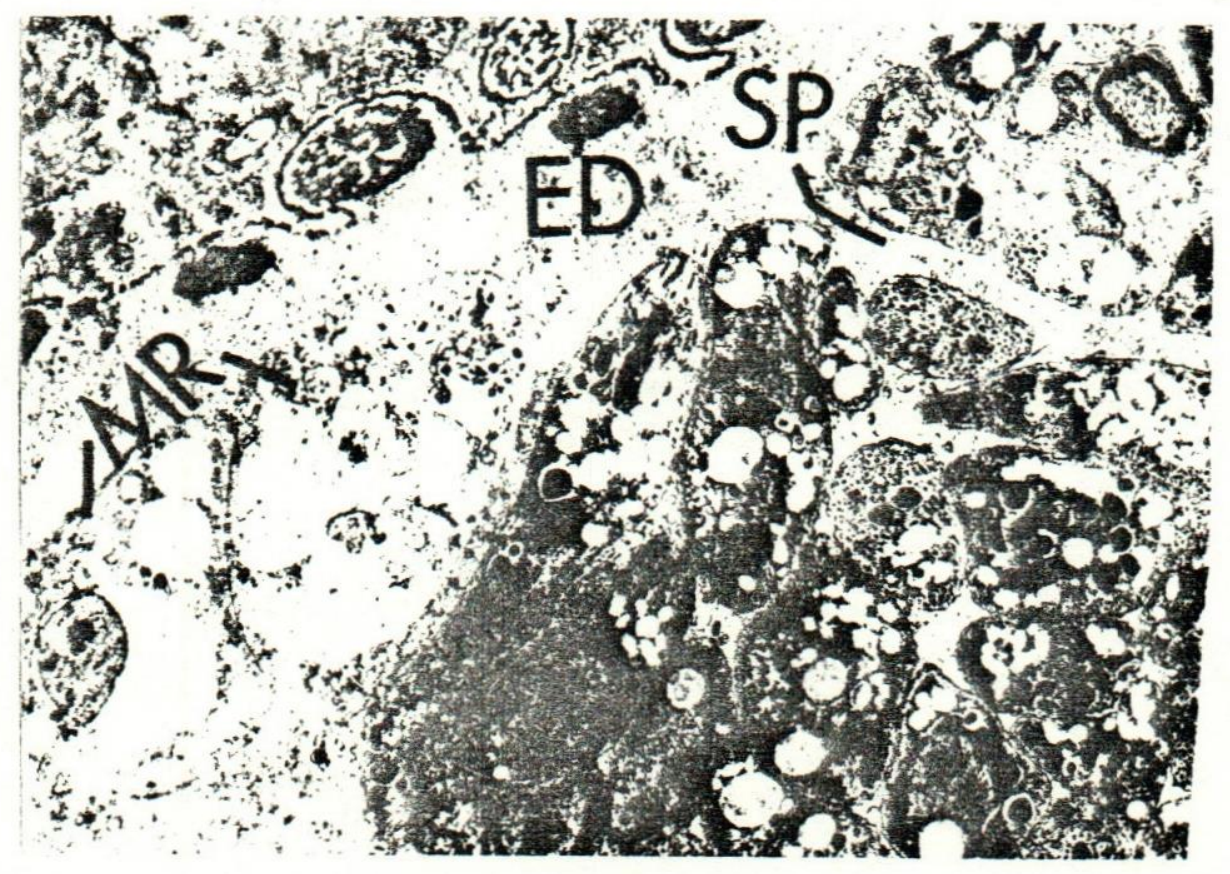

(Fig. 6): Electron micrograph of skunk Sarcocystis showing metrocytes, septa and electron dense bodies. (X 5,000). 


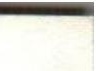

$-$ 


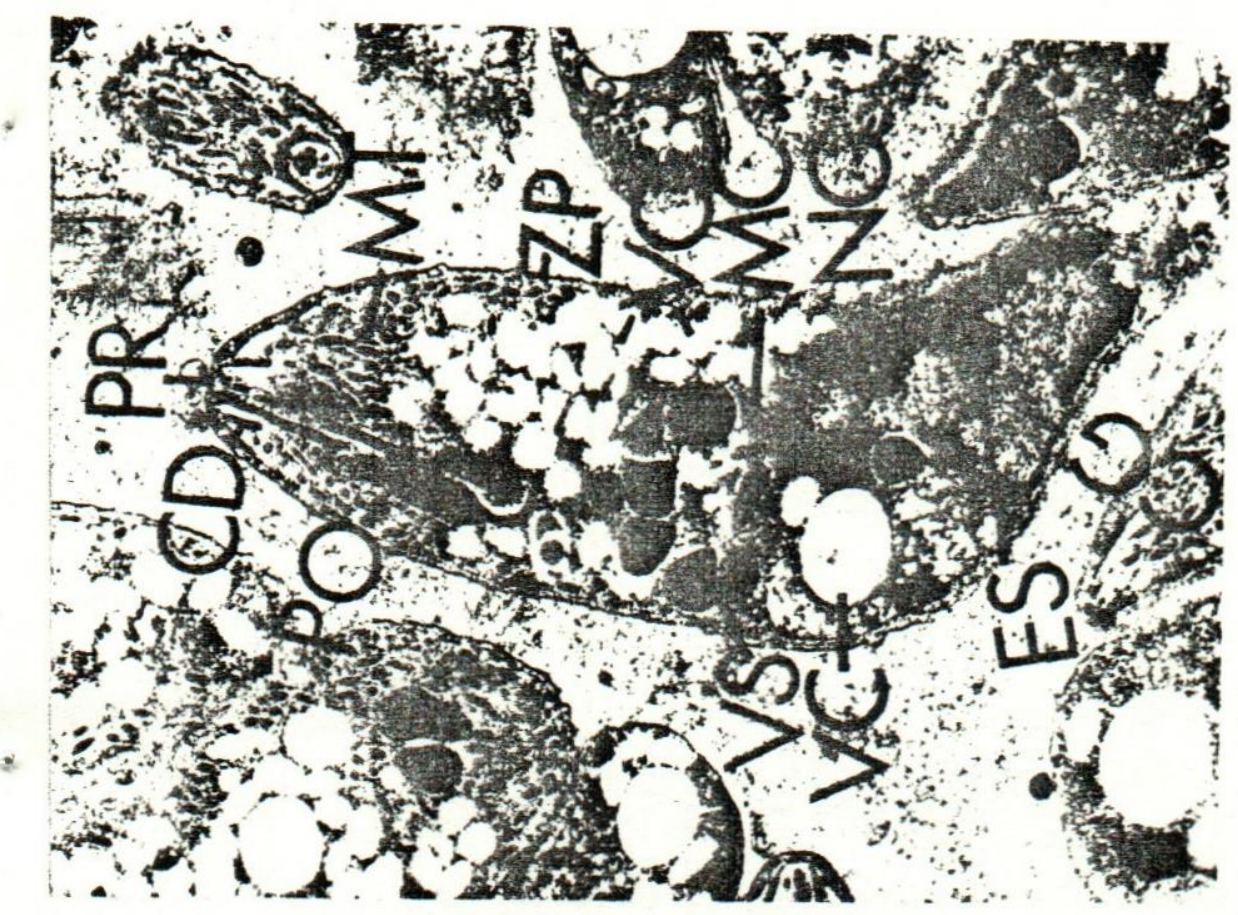

(Fig. 7): Electron micrograph of skunk Sarcocystis showing the fine structure of a zoite (X 10,000).

(Fig. 8): Electron micrograph of skunk Sarcocystis showing a highly magnified micropyle. (x 70,000).

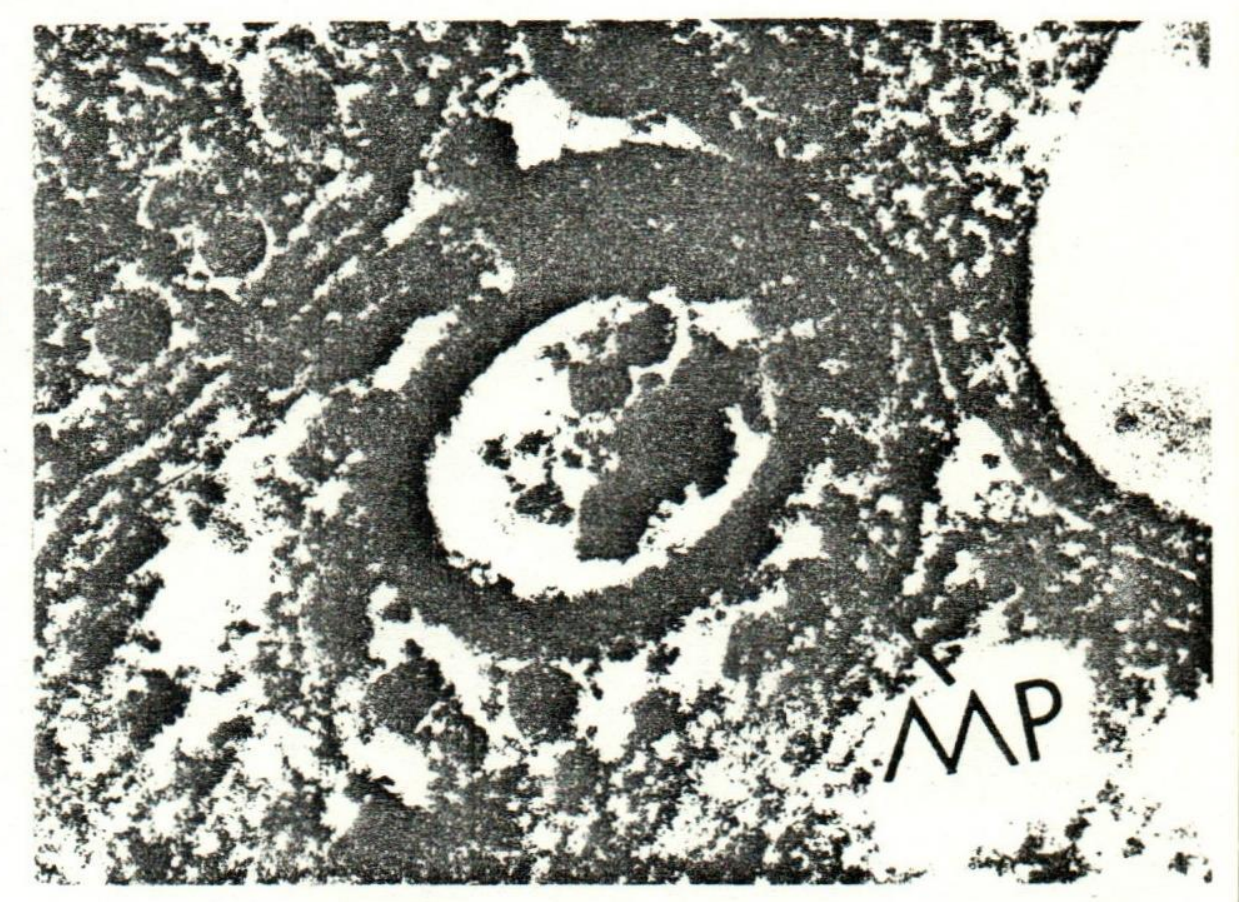

ABBREVIATIONS USED ON MICROGRAPHS

$\begin{array}{llll}\text { Chromatin granule } & \text { CG } & \text { Mitoehondrion } & \text { MC } \\ \text { Conoid } & \text { CD } & \text { Nucleus } & \text { NC } \\ \text { Cyst wall, outer layer } & \text { CW1 } & \text { Paired organelle } & \text { PO } \\ \text { Cyst wall, inner layer } & \text { CW2 } & \text { Papilla } & \text { PP } \\ \text { Endosome } & \text { ES } & \text { Polar ring } & \text { PR } \\ \text { Electron dense body } & \text { ED } & \text { Septa } & \text { SP } \\ \text { Filamentous fibrils bun. } & \text { FF } & \text { Vacuole, unstained } & \text { VC } \\ \text { Host mitochondria } & \text { HM } & \text { Vesiele } & \text { VS } \\ \text { Metrocyte } & \text { MR } & \text { Villi } & \text { VI } \\ \text { Micropyle } & \text { MP } & \text { Villus pellicle } & \text { VP } \\ \text { Microtubules } & \text { MT } & \text { Zoite pellicle } & \text { ZP }\end{array}$


